\title{
Chechen Frontier in the Socio-Cultural Space of East Kazakhstan in Conditions of Deportation
}

\author{
Albina S. Zhanbossinova ${ }^{+*}$ and Ainur T. Kazbekova'
}

\section{Abstract}

The article covers the history of the totalitarian regime in the 40s of the 20thCentury on the territory of the Soviet Union, including Kazakhstan as an integral part of the Soviet empire. The chronological framework of events is connected with the Second World War, namely with the aggression of the Third Reich against the USSR. The regime of everyday military life reinforced the repressive actions of the Soviet government, the point was directed against the peoples accused of loyalty to the German troops. Chechens who were deported to Kazakhstan, including East Kazakhstan on 23 February 1944, became one of such ethnic groups affected by the totalitarian policy.

The methodological basis of the study was an interdisciplinary approach, theoretical and methodological concepts of 'collective memory' in the projection of collective-individual, 'cultural memory', and 'generational memory'.

In the article, based on a wide range of sources and materials, the integration processes of Chechens and the ethnic dialogue with the Kazakh ethnic group and ethnic palette residing in East Kazakhstan in terms of production and outside its sphere are analysed.

The research introduces to the scientific circulation archival and documentary sources and records of materials collected as a result of field expeditions, allowing to show the interaction of Chechens with the local population in conditions of deportation, with an attempt to improve social status by participating in socio-economic processes and preserving ethnic identity.

The authors believe that the strategy of behaviour and the adaptation of the Chechen ethnos differed by their internal attitude to the status of the deported; their dispersed state and frontier conditions determined the individual strategy and tactics of survival.

Keywords: World War II, Great Patriotic War, Repression, Deportation, Chechens, Special Settlement, SocioCultural Space of East Kazakhstan

\footnotetext{
${ }^{\dagger}$ Doctor of Historical Sciences, Professor of Department of History of Kazakhstan and Social-Humanitarian Disciplines, Sarsen Amanzholov East Kazakhstan State University, Kazakhstan

${ }^{*}$ Corresponding Author, Emails: zhanbossinovaa@gmail.com, sovetuk@rambler.ru

í Candidate of Historical Sciences, Associate Professor of the Department of History of Kazakhstan and SocioHumanitarian Disciplines, Sarsen Amanzholov East Kazakhstan State University, Kazakhstan

(C) 2019 Zhanbossinova \& Kazbekova. This is an Open Access article distributed under the terms of the Creative Commons Attribution License (http://creativecommons.org/licenses/by/2.0), which permits unrestricted use, distribution, and reproduction in any medium, provided the original work is properly cited.
} 


\section{Introduction}

The history of the Soviet past is so controversial that it is still the subject of close attention of modern historical science (Middlemiss, 2017). Given the new methodological trends, the events of Soviet history moved from the pretentious presentation to the level of anthropological understanding, from the negative tragic perception to an attempt to study the experience of Soviet construction and technological advances. An important influence was made by the "New Historical Science" by launching an intellectual reload of the postSoviet space. Reliance on its theoretical and methodological concepts led to a reassessment of past events in the context of interdisciplinary approaches to the research paradigm.

The archival revolution of the 90s of the last century just opened the veil of the mystery of Soviet history. At the current stage, there is active methodological research and expansion of the spatial and deep horizons of the Soviet problems. The emergence of social history in foreign historiography at the end of the 20thCentury drew attention to the social processes and social structures of the society giving them an anthropological hue, highlighting a person against the backdrop of macro and micro events.

One can attribute the history of deportations, a kind of the communist experiment to the classic of the genre, describing the tragic events of the Soviet past. The Kazakh Soviet Socialist Republic became the location for the forcibly resettled Koreans, Ingush, Poles, Kurds, Germans, Chechens, etc. East Kazakhstan became the location of deported Germans, Poles and Chechens.

The experience of the Soviet deportation cannot be viewed in isolation from world history. Deportation overthrows understanding of the world justice and existence of the right (Hasselberg, 2016: 145). In the history of the Third Reich, there are pages of deportation of Jews: "In one of the first books on the history of Jews in the Netherlands during the Second World War, published in 1946, Sam de Wolff described how people reacted to being deported. He depicted an early morning scene in Amsterdam - it was 1942, two years after the Germans invaded the country, and the Nazis started the deportation of the Jews from the Dutch capital" (Braber, 2013: 1).

The modern world also shows us examples of imperfect immigration policy and deportation. For example, the idea of the Great Wall of America (actively supported by Donald Trump) was proposed to prevent immigration from Latin America into the USA. With that, the plan would inconvenience tourists, workers, students, and others who cross the border daily. Many talks of the related financial costs and damage to the environment (Cameron, 2017).

Due to the Rohingya crisis, more than 730,000 Rohingya have been driven into Bangladesh (as of January 2019). Over half of them are children. Myanmar denies persecuting the Rohingya, a stateless minority (Pedersen, 2015).

The relevance of the proposed problems lies in the fact that the integration of the Chechen people into the socio-cultural space of East Kazakhstan has proved to be a difficult task. The contradiction of the frontier was that two lines of intersection could be distinguished. On the one hand, the leaders and their position; on the other hand - population and their position. The regional authorities made every effort to provide the settlers with everything necessary, but at the local level, the important problems of the Chechens were ignored. The behaviour of the local population towards special settlers varied from kindness to murder (Scarborough, 2017). The subjects of the relationship were manifested differently; the sociocultural space of the frontier to some extent determined the ethnological dialogue with the Kazakh ethnos with the Muslim culture and the ethnic palette that resided in East Kazakhstan in the conditions of production and outside its sphere.

The problem of forced resettlement in the conditions of the repressive policy of the Soviet state at the initial stage of the archival revolution was of a conjuncture nature. The authors 
seemed to compete with the number of sensational materials. It must be admitted that the first works that affected deportation as a policy of the Soviet state appeared in foreign historiography.

Modern foreign historiography considers deportation as a war of the Soviet state against the 'fifth column' (Burds, 2007), as 'ethnic cleansing' (Gelb, 2000), as an 'ethnic conflict' (Martin, 1999), an attempt to analyse the assimilation of deported peoples (Scarborough, 2017), the use of anthropological approach (Lackwood, 2017), etc. Foreign experts of the Soviets consider the problems of repression and deportation in the focus of the term 'Stalinism' analysing the content of fragmentary memory, where the memory of Stalinism is regarded as a memory of state terror (Roginskij, 2017).

Some authors, e.g. J. Burds believe, that the indirect cause of the deportation of the Chechen people during the war of the Soviet state with Germany was the Caucasus, which became a stumbling block during the Second World War because of its strategic position and, as he writes "... that supplied more than 90 percent of Soviet gas and fuel reserves"(Burds, 2007:293). He also believes that the Chechen people led a guerrilla war in the Caucasus Mountains with the NKVD (Burds, 2007).

According to I. Hasselberg, "The Soviet forced population movements generated earlier literature on deportation, dating back to the 1960s. As Walters (2002) notes, deportation is but one form of expulsion. Others include religious expulsion, the transportation of criminals; political exile and population transfers. Soviet forced population transfers removed people from their place of birth and relocated them to a designated area. Their removability was grounded on who they were (such as Chechens, Polish, or Ingush). Deportation, on the other hand, is intended to forcibly remove a person from their place of residence to their prospective country of origin. Here, deportability tends to be grounded on lack

\footnotetext{
${ }^{1}$ The historical construct of the war against fascism is reflected in the name 'Great Patriotic War', which began on 22 June 1941, when Germany started offensive
}

of legal immigration status or the undesirable actions of the individual - such as moral behaviour, political ideology, and criminal conviction. However, these are not neat categories" (Hasselberg, 2016: 23-24).

Several foreign authors considered ethnic cleansing of Poles (Musial, 2013), Crimean Tatars (Williams, 2002), Germans (Pohl, 2015), etc. The study of the deportation history of the Crimean Tatars showed that generational memory forms the behaviour of the descendants of the deportees, laying the foundations for their political selectivity (Lupu and Peisakhin, 2017).

Russian historical science has made a significant contribution to the coverage of the problems of forced resettlement of peoples, their subsequent rehabilitation. Particular mention should be made of the works of N.F. Bugay (Bugay, 2003; 2011; 2012), most of which deal with the issues of historiography and source study of forced migrations of 'desecrated', 'punished' peoples whose 'unreliability' caused their eviction (Bugay, 2003; 2011; 2012).

The geography of forced resettlement, the deportation of the Chechens and Ingushes to Kazakhstan (Karaganda region), was considered by P. Polyan (1999; 2001). The studies of Kazakhstani historiography on the proposed subject matter affect the following blocks:

- ethnic cleansing within the framework of spy mania, fear of terrorism, diversions, reflected in the directive letters published by the State Department of State Security of the NKVD in early 1937, where the main priority was given to the prevention of the espionage-terrorist activities of the alleged enemy of the forthcoming war;

- forced resettlement and secondary repression in the places of the new settlement, which was realised on the eve, during and after the Great Patriotic War; $^{1}$

military operations without declaring war, and ended on 09 May 1945 - the surrender day of Adolf Hitler. 
- compulsory labour service, when all the able-bodied population of immigrants was mobilised in working columns.

A historiographical review of the problem shows that the researchers expanded the information field on the history of deportations. At the same time, the analysis of contemporary foreign publications on the presented topic demonstrates the range of collocations used in the title, which is not distinguished by a wide variety, is a common scientific lexicon for many authors, mainly: 'The Soviet experiment', "mass killing and genocide", "Terror against nations", "Ethnic cleansing", "Ethnic and national purges", "The target groups", "Soviet Deportations", "Nationality as a stigma", "Special settlements", "The Repression of Soviet Koreans", "Forced Deportation", that is, this is terror, and repression, and ethnic cleansing. Only in two cases did the names sound: "The Soviet war against the 'fifth columnists': The case of Chechnya, 1942-44."

In the theoretical and methodological terms, the above works, despite the scatter of opinions and assessments, are one in opposition to the Soviet repressive system and the repressed ethnos, as victims of terror. While writing, we relied on the well-known publications of N. Bugay (2003; $2011 ; 2012)$. The scarcity of the source study base did not allow them to reconstruct the full picture of the events of those years. Typical for publications is the lack of archival data, that is, primary sources, fragmented presentation and compilation of well-known published materials.

The history of the deportation of the Chechen people to the territory of the East Kazakhstan region, despite the considerable volume of printed materials, both in Russia, Kazakhstan and abroad, did not become a subject of detailed research from the position of local historical parameters at the intersection of interdisciplinary relations.

The absence of direct scientific developments on the issue determines the purpose of the research. In other words, central to this research is to reveal the uniqueness of the Chechen frontier in the socio-cultural space of local history (East Kazakhstan) under the conditions of deportation, and the introduction into the scientific circulation of new archival materials that make it possible to uncover unknown pages of the history of special settlers.

The authors propose to consider the frontier zone according to T. Barrett on the basis of a complex interdisciplinary analysis, where the object of the study is the territory of East Kazakhstan, the subject of research is the history of the deportation and integration of the Chechen ethnos into the socio-cultural space of East Kazakhstan. The next section discusses the methods.

\section{Methods}

The Archive of the President of the Republic of Kazakhstan served as a source base, in particular, Fund 708 - of the Central Committee of the Communist Party of Kazakhstan attracted our attention. There is a considerable number of documents there revealing the history of deportation to the territory of Kazakhstan, including East Kazakhstan. Of particular interest is the correspondence of state authorities, orders, memoranda, statistical information, representing the daily routine of workflow, behind which are the destinies of hundreds of thousands of people.

Appealing to the local history, we found the materials of the State Archives of the East Kazakhstan Region (SAEKR) undoubtedly valuable, as Fund No.1-p of the East Kazakhstan Regional Committee of the Communist Party of Kazakhstan, No.642 - of the East Kazakhstan Regional Administration of the Ministry of Internal Affairs, No.130-p - of the Leninogorsk city Committee of the Communist Party of Kazakhstan contain all materials concerning reception and accommodation of deported Chechens on the territory of the region. The documents of these funds represent the most extensive group of sources - organisational and administrative documents, records of meetings, planning documents, current correspondence of the Regional Committee of the Communist Party (of Bolsheviks) with the central authorities.

We have researched archival materials of the Department of Internal Affairs of the East 
Kazakhstan region, with documents of the secondarily repressed Chechen special settlers under Articles 58-10 anti-Soviet propaganda. These documents are introduced in scientific circulation for the first time.

Discovered materials contribute to the restoration of an objective picture of everyday life, economic and domestic employment of Chechen special settlers. These cases are the most informative, which made it possible to recreate the geography of resettlement in the districts of the region, the number of the special contingent in the context of the districts, and highlight the problems of material and economic accommodation for Chechen special settlers. The wagon lists of Chechen special settlers allow to establish the main areas of their eviction, characterise the age and sex composition, and show information about the losses among special settlers en route.

Some of the SAEKR sources are introduced into scientific circulation for the first time.

When writing the article, the available scientific publications on the presented research topic were taken into account. Methodology and methods of research is a complex interdisciplinary approach. The works of Russian historians L. Repina (2011), I. Savelieva (2006), which laid the theoretical and methodological foundations of interdisciplinary communications, became fundamental.

Modern scientific research on the problems of "cultural (historical) memory" is evidence of the formation of interdisciplinary approaches and the methodology of social and humanitarian research. The authors relied on the theoretical and methodological concepts of the "collective memory" laid by M. Halbwachs (2005:40), the collective-individual projection, the "cultural memory" by Ya. Assman (2004), the semiotics of memory history, K. Mannheim's "generation memory", general life experience (Mannheim 1998:31).

In terms of interdisciplinary research and actualisation of the format of the terminology used, the authors defined the following concepts: "collective memory," "collective memories," "cultural memory," "historical memory," "generation memory." The variability of the discourse of memory is multifaceted and meaningfully extensive. The memory of the deportation from the status of the family frame goes into the category of public representation.

The reliance on the theoretical concepts of modern historical science allowed authors to comprehend documentary artefacts, that is, archival materials, historical sources in the focus of interaction with sociocultural structures that influenced their content.

The article is based on general scientific methods (analysis, synthesis, deduction, induction, statistical method); special historical methods; scientific methods at the intersection of interdisciplinary approaches, including the method of oral questioning.

Overall, the whole range of methods used allowed revealing the research topic, to understand its deep processes and to identify the peculiarity of the implementation of deportation policy in the prism of oral memoirs. The results are discussed in the following sections.

\section{Results}

The document that initiated the deportation of the Chechen people was the State Defense Committee Resolution No. 5073 top secret "On measures to accommodate special settlers within the Kazakh and Kirghiz Soviet Socialist Republics" of 31 January 1944 (Bugay, 2003). At the same time, preparations for the total deportation of Chechens and Ingush began in October 1943, Kazakhstan and Kyrgyzstan being identified as the location of their future settlement. The planned number of special settlers was varied and adjusted until the "Chechevitsa" ("Lentils") operation. The route plan for the transportation of deported Chechens took into account the smallest nuances, such as the number of convoys, stations along the route, the number of accompanying operatives.

The wagon lists of deported Chechens, despite some confusion and inaccuracy, allow determining the age-sex composition and 
historical geography of places of eviction. Deportees from Shatoev, Shalinsky, Vvedensky, Ataginsky districts of the Chechen-Ingush Autonomous Soviet Socialist Republic arrived in the East Kazakhstan region in four echelons (The State Archives of the East Kazakhstan Region (from now on referred to as SAEKR).

For a month or so, young children, older men, women and men were travelling in freight cars that were not designed to transport people, as confirmed by the list of special settlersChechens. The inhuman conditions of transportation of the deportees caused the high mortality of children and older adults.

The memories of the deportees kept the tragedy of the carriage movement:

We travelled for a very long time, about a month. On the road, there were snowstorms. We did not have snowstorms in the Caucasus. It was very hard - cold, hungry. People were dying. We were not allowed to bury them. If there was time, then men quickly buried the dead in the snow. Sick and dead were pulled out from the cars and thrown like dogs. Somewhere the train stopped, and accidentally I saw in the crack of the car that my brother was taken out from a nearby car and placed on the snow. He was alive and turned his head. He only had time to look after. So they left him alive to die (SAEKR: 7-149).

One of the most challenging memory stories is the time of expulsion. The family frame under the influence of cultural trauma retained the pain of humiliation, loss of close people and the patrimonial nest, indifference and hatred on the part of escorts; accompanying elements such as hunger, illnesses, and death are considered only as clan derogating consequences.

The children of deportees remember the process of resettlement from their parents' words:

I remember it from the words of my mother, evicted during 24 hours on February 23,1944 . It was snowing. It was cold. They evicted people in what they were wearing, not allowing them to take anything with them. Everything was left: houses, cattle. Mother told me they understood that they would be taken far away. She fed the cattle, gave them a lot of hay, and closed the house. Then they were made to walk from the village of Chechen-Aul to the city of Grozny. There they were placed into the dirty carriages of the freight car, where they had transported cattle, coal and so on. There was nowhere to sit. In the car, there were children, old men, women and sick people who could not walk, that is where all the hell was. People began to die of cold and hunger; there were no living conditions. When the train stopped, soldiers entered the car, checked to see if there were any dead in the car. People tried not to show, hide the dead, so as not to let the soldiers take them out and leave outside for birds or animals. However, they were taken out and stacked, and the train moved further. When the train stopped near some village, the corpses were taken out of the cars, and people buried the dead in the snow or begged the local people to bury them. That's how my family was brought to Leninogorsk, now Ridder (Zhanbossinova and Kazbekova, 2014).

The generation memory of deportation is formed from oral legends, stories. The transformation of individual memory into social is observed.

Bertan Bertanov, ${ }^{2}$ former special settler, who came from the village of Ushkaloy of the Chechen-Ingush ASSR, recalls:

I was then about 5 years old. They brought us to Ust-Kamenogorsk, left near the condenser plant, right in the mountains, without any shelter. There were no building materials. My father himself built a booth from stones. Suffering, hunger, cold - that's what I

\footnotetext{
${ }^{2}$ Informants' names were changed
} 
remember. There was nothing, brown bread was given for cards. They used to eat different kinds of grass. It was difficult to find edible grass. Being children, we searched the grass in the spring. There was a terrible famine. Frosts were strong. The great number of people, dampness, and hunger gave rise to mass illnesses (Zhanbossinova and Kazbekova, 2014).

The Chechen people experienced a terrible tragedy; the sufferings of the entire people were left forever in the historical memory. The phrase "even the weather itself was crying" in the mouth of a person, a child who survived deportation, reflects that emotional shock. Kairat Kairatov (Zhanbossinova and Kazbekova, 2014) was most struck by the fact that those soldiers, who lived nearby, forgetting about the mountaineers' hospitality, treated them as criminals. He said:

I remember everything like now. I went to first grade then. It was 1944, on 23 February.

We had a new house which our father had built. Later he was taken to the front. The soldiers lived in our house. It was called "The White School" in our country. The male population was gathered there. I went there by car with my uncle, who had come from Georgia. He worked there, so he was not immediately taken. Soldiers surrounded the people in a triple ring. Some of them wanted to escape. They were locked in the barn in the stable. However, we returned with my uncle. The soldiers drove the Studebakers, but those soldiers who were located in our house ... we gave them food, clothes. They were loading food, and my stepmother was putting in my clothes. We had two dogs, a Caucasian and a puppy. I remember when we were put into the car, the small dog bit soldiers, although they used to pat, feed, and hold it. There grew quinces in the yard, and the dogs hid behind them. One of the soldiers wanted to shoot the dogs, but I got hold of him, I still remember that. It was early morning. In the yard, there was a terrible noise: the dogs were barking, the cattle were howling, the hens clucked. Everyone was crying. Even the weather itself was crying. Two Studebakers brought us to Ermolovka station. I do not know what it is called now. There was a mountain of grain; all the clothes were piled up. All the things were taken away. The soldiers took us into a large four-tailed wagon. As I now know, this was the last time people were forced to move. The cars were stopped every 3-10 hours. People had to go for their natural needs in one place. If women ran in another direction, the soldiers shot. The Chechens did not have this, they had their own etiquette. Many died due to rupture of the bladder. Women gave births, died in wagons. The hatches were closed if you opened the hatch from the inside, they shot from the assault rifle. And at last, they transported us to Zharma..." (Zhanbossinova and Kazbekova, 2016).

East Kazakhstan was preparing to meet the Chechen people on its land. The regional administration, the Leninogorsk City Committee of the Communist Party (of Bolsheviks) adopted Resolution of 02 February, 1944 "On measures to accommodate special settlers" based on directives from the centre. One thousand two hundred ten collective farms $(6,065$ people) were to take special settlers, accommodate and employ them in industrial enterprises and collective farms in Leninogorsk, according to a preliminary developed plan. Those were Forestry (415 families), Altaystroy Trust (500 families), Power plant (150 families), Ubinsky Forestry (100 families), Lime Quarry and "The Second Five-Year Plan" Farm (30 families), Industrial Plant and Industrial Artel (15 families). The City Committee ordered the heads of enterprises to prepare in advance the points of reception, the necessary amount of housing stock, food for special settlers (Zhanbossinova and Kazbekova, 2014). 
The current situation adjusted continuously the plans for the resettlement of Chechens in the areas of the East Kazakhstan region, which reflected not only in the change in the number of locations in the regions but also in the geography of the forthcoming resettlement. In the memorandum to K. Zh. Shayakhmetov, the secretary of the Central Committee of the Communist Party (of Bolsheviks) "On the course of preparation for the admission and placement of special settlers in the East Kazakhstan region" of 06 March , 1944, it was indicated that it was planned to accommodate 6,000 families or 30,000 special settlers, in eight districts, including Leninogorsky $-6,650$, Kirov $-8,750$, Verkh-Ubinsky - 2,000, Predgorny - 2,500, Bukhtarminsky - 2,000, Ulan - 3,050, Shemonaihinsky -2,900 and Tavrichesky - 2,250 people. It was supposed to use 11 railway stations for meeting immigrants (SAEKR: 7-149).

Accommodation of special contingent in the region determined the party algorithm for implementing the directives of the centre. First of all, commissions were set up to organise the reception and resettlement of the incoming contingent in the receiving regions; plans of measures for the reception, resettlement, employment and agent-operative services for special settlers were drawn up, responsible executors and terms of execution were determined. Of course, the plan adopted on paper was fundamentally different from the realities of everyday life of wartime: the deported Chechens were transported to places of dislocation untimely, which was explained by both objective and subjective reasons.

The head of the "Kazgidroenergostroy" Trust in a letter to the centre stated that "In mid-March this year, at the insistence of the regional organisations of the East Kazakhstan region, the special contingent from the Chechen-Ingush Autonomous Soviet Socialist Republic arrived in the workers' settlements of "Irtyshgesstroi". The placement of the special contingent was caused by impassability and lack of navigation on the Irtysh River, which prevented regional organisations from sending people to the districts. The housing was temporary, with a gross violation of sanitary standards and elementary living conditions. Men, women and children in the quantity of 3,400 people lived in temporary residential and hastily adapted standard barracks with 2-tiered bunks, which were hardly permissible to place more than 2,000 people there" (Archive of the President of the Republic of Kazakhstan (from now on referred to as AP RK). Bureaucratic delays had a detrimental effect on the status of the accommodation issue of special settlers, given that in the situation of forced placement, they were not provided with the basic conditions necessary for life support, not to mention food rations.

The geographic location of special settlers was determined by the requests of the main branches of the economy of Kazakhstan - nonferrous metallurgy, forestry, agriculture. For the employment of special settlers, in the first place, industrial enterprises, timber enterprises and collective farms were selected, in which there were free land areas, and a shortage of labour was felt.

The analysis of archival materials carried out by the authors made it possible to establish the geography of the resettlement of Chechen special settlers in the region. The Chechens who arrived on the territory of East Kazakhstan were deployed in eight districts of the region. As of 01 September 1944, there were 6,906 families with Chechen settlers in the East Kazakhstan region, with a population of 29,238 people. The largest concentration of special settlers-Chechens was observed in Leninogorsk (2,481 families, 10,937 people) and Kirovsky districts, taking into account Ablaketka settlement (1,569 families, 6,542 people) (AP RK: 186). The Chechens did not settle in the border areas of the region.

According to archival data, on 01 April 1945 in the East Kazakhstan region, there were special settlers-Chechens - 6,320 families, 24,719 people. The geography of settlement on 01 April 1945 by districts of the region shows that the greatest concentration of Chechens was observed in Leninogorsk (8,808 people, 2,268 families) and Kirovsky (6,055 people, 1,463 families) districts (SAEKR: 2750). 
Leninogorsk, a small provincial city of the East Kazakhstan region during the war, played a leading role in the production of weapons for the front. It was here, in view of the labour shortage in the enterprises of non-ferrous and ferrous metallurgy, cooperative and local industry, in the interval from 20 March to 01 July 1944, 2,340 families of Chechen special settlers arrived, with a total of 11,179 people, including 5,431 ablebodied men, registered for work in enterprises and organisations $-4,295$ people (SAEKR: 2741).

The arrived special settlers faced a whole complex of problems, first of all - housing. Leninogorsk mine administration placed settlers in the drying sheds of the brick factory. Those who were lucky to live in the house found themselves in extremely cramped conditions: the living area per person was from 0.75 to 1.25 sq. $m$, in completely unsanitary conditions caused by lack of water. The settlers faced not only the problem of housing and living conditions and the lack of food but also the inability to find work for family members. The ration of one worker to a large family was insufficient, hence the famine, exhaustion, illnesses. At the same time, the party bodies arranged endless commissions to verify the implementation of the programme provisions for the placement and employment of special settlers. On the basis of the results of the inspections, they were considered unsatisfactory, but this did not solve the issues of providing products and resolving the situation; on the contrary, it was further aggravated.

Archives keep many materials regarding the facts of high morbidity and mortality of special settlers-Chechens. On August 3, 1944, under the stamp "top secret", the head of the regional Health Department reported to the regional Executive Committee: "Lately, among the special settlers in the East Kazakhstan region, there has been large mortality due to severe dystrophy. During June-July, 87 people died on the construction site of the Kirovsky district, which is $25 \%$ of the total number of arrivals" (AP RK: 186).
Given, the lack of clothing and footwear for many special settlers, the patients from the Chechen village could not go to the hospital, let alone go to work. The Chechens did not receive medical assistance in the place of residence (SAEKR: 2739).

A concomitant consequence of the lack of warm clothes and shoes was the inability to go to work, which meant automatic non-receipt of rations, constant malnutrition that led to severe exhaustion and mortality. According to incomplete data, as of 01 January 1945, of the total number of Chechens, 382 people died; of which 190 were children. These are not exact figures since the number of dying was hidden from official authorities: "... the dead are not registered anywhere, but buried secretly from commandants. The cause of mortality was mainly dystrophy and gastric diseases" (SAEKR: 2750). Between 01 September 1944 and 01 April 1945 , the number of Chechens decreased by $15.5 \% .^{3}$ (AP RK: 186).

Party organs tried to control the situation with special settlers, solve problem issues with the provision, employment, and housing. On the instruction of Zh. Shayakhmetov, the Secretary of the Central Committee of the Communist Party (of Bolsheviks) of Kazakhstan, the economic and labour situations of Chechen special settlers from the North Caucasus to the east of Kazakhstan were checked. The poor conditions of the special settlers in the East Kazakhstan region were also ascertained in a certificate dated 18 October 1944, signed by D. Kunayev (future secretary of the Communist Party of the Kazakh Soviet Socialist Republic), which said on the extremely unfavourable situation of special settlers who continued to live in farm buildings, clubs and other premises not adapted for living, on cases of mocking attitudes toward special settlers, beatings and even killing them, about the impunity of those who had committed those acts (AP RK: 186).

Many heads of departments of the "Altaystroy" trust for the purpose of resolving the housing

\footnotetext{
${ }^{3}$ Note: The calculation was made by the author on the basis of the archival data of SAEKR F.1p. I.1. Sh. 2750.
} 
issue acted illegally. For example, the director of Regional Construction and Metallurgical Department-2 of the "Altaystroy" trust took five families consisting of 24 special-settlers with children out of the Chechen town into the open sky on the territory of the artel's tannery "Labor Victory", placing people in a semi-disintegrated building of a leather factory with an area of 25 sq. m. The director of Regional Construction and Metallurgical Department-3 of the "Altaystroy" trust did the same thing, taking out eight families consisting of 76 people to the outskirts of the village and placing special settlers in the open field, telling them that they should build housing there (SAEKR: 2750). The administration of industrial facilities, where the special settlers were sent, wanted to get rid of them if possible, passing through a medical examination of their unfitness to work, which led to the dismissal and deterioration of their financial situation. The behaviour of the chairman of the collective farm Krasnaya Niva is the best way to show the attitude of the local authorities to special settlers: "Special settlers must be shot and drowned in the river, as we have a lot to do without them" (SAEKR: 2739).

In areas of resettlement, the Chechen people faced many problems caused by irresponsibility and callousness, and sometimes by the huge workload of the district authorities. Together, this led to the inopportune acceptance of Chechens to the collective farms, to the wrong allocating of household plots, or giving out the rations or to the directly opposite decision, where instead of giving out provision for five days, collective farms gave the rations for 25 days. Hungry special settlers ate the products quickly, and as a result, by the end of the month remained without any products.

Despite the complexity and inconsistency of integration of the Chechen people, the special resettlement frontier tried to improve its social status by an attempt to participate in social and economic processes actively and discuss the possibility of preserving the group's ethnic identity. The outer boundaries of the Chechen frontier were blurred due to their disperse state, the latter being the result of their forcible displacement. As a strategy for adapting deported Chechens, it is worthwhile to note the construction of temporary shelters, the establishment of relations with the local population, which was also uneasy in the wartime conditions, working in labour collectives.

Workers of the special commandant's offices held meetings with Chechens about the need to repair the housing. Most of them started to construct the adobe and plastered the walls of their premises without waiting for help with building materials.

Earnings of those who worked conscientiously varied from 30 to 55 rubles. Special migrants who worked in agricultural areas, for example, in livestock farms, were provided with food, as evidenced by the materials of the case: "... we were provided with bread, milk, each person was given 1-1.2 liters of milk ..." (SAEKR: 3420).

In the forest areas, despite deplorable working conditions, Chechens worked half-starved, and in some cases without clothes and barefoot "... in the logging operation team of Regional Construction and Metallurgical Department -2, five Chechens worked, four of whom, Abdurzakov, Uslanov, the Yahihsanovs, Marzhan and Tamara were barefoot" (SAEKR: 2750), and yet some of them, like Israilov, Satuev, completed $120-150 \%$ of the plan.

It was noted at the Bureau of the East Kazakhstan Regional Committee that because of the establishment of normal living conditions and human relations to special settlers, in some enterprises of the region, such as Belousovsky, Berezovsky mine departments, Ubaredmet, collective farms of the Leninsky district, the attitude of Chechen workers to work improved. Many of them systematically exceeded the plans of output: "Two brigades of special settlers, Abdulvagapov - 26 people and Tashayev - 13 people in the forest completed $200 \%$ of the plan, and the Abdulvagapov's brigade held the passing banner of the site for a long time" (SAEKR: 2750).

At the Belousovsky mine among the Chechens, there were 39 advanced workers and 5 Stakhanovites, such as Magomadov, burmaker - 
$187 \%$ of the plan, Makhmudov, rigger - $144 \%$ (SAEKR: 2741). The leaders of the Leninogorsk mine department in July 1946 noted that the share of violations of labour discipline is less among Chechen special settlers than among other workers. There were no cases of desertion. Chechen workers such as Stakhanovite Osmayev, burmaker - $215 \%$ of the plan, Kadyev $278 \%$, Mahmudov - $200 \%$ were specially honoured (Archive of Internal Affairs Department of the East-Kazakhstan region (hereinafter referred to as AIAD EKR).

Rumours of a possible early return to their homeland were constantly circulating among the Chechen people. In May 1944 in the village of Kokpekty, where special settlers Chechens lived, the chairman of the collective farm "Unity" saw their collective farmers, Chechen women in the market with things put up for sale. To his question: "What are you doing here?" they answered:

We came to the market to sell things - we are preparing to leave for the North Caucasus." The chairman having clarified the reasons for their appearance, conducted an explanatory conversation with them, and sent them to the collective farm, advising not to sell any things, stating that "no one will go anywhere, return to the collective farm and work (SAEKR: 3997).

At the same time, among the local leaders, there were also such people as the chairman of the factory committee declared:

We cannot consider them the Stakhanovites, in spite of the fact that they overfulfil the norms, as we do not have any instructions from above. That is why the conditions created for the Stakhanovites and the Chechens are similar, but we do not practise the popularisation of Chechens who fulfil the norms (AP RK: 186).

The Maloubinsk village council went even further by deciding at the collective farmers' meeting in relation to the special settlers Chechens:
... there will not be any help from us, let them not rely on the collective farm, but work themselves, for the collective farm or be hired by collective farmers. But we do not have any funds for them (SAEKR: 2750).

The reports on the shortcomings of economic, labour and housing conditions of special settlers from the North Caucasus include the facts of unauthorised expulsion of Chechens from the collective farm, beatings, even murders.

... collective farmer Nikitin on the collective farm "Khleborob" in order to free his apartment from a special settler Chechen, Isayev, killed him with a shovel to death, for which he was sentenced to 5 years in prison (SAEKR: 2750).

In the post-war period, the Chechens said:

... the war is over now, and we have started peaceful work, shipping the forest to the country. We also help fulfill the 4th Stalin Five-Year Plan ahead of schedule (AIAD EKR: 3521).

On the general background of life in the conditions of deportation, anger and depression were observed. Archival documents mark cases of mocking attitudes toward special settlers, beatings and even killing. Almaev Vassa:

The Chechens have come to an end, everyone dies and I will soon die. I do not want to register in the party; no one needs me any longer. I used to work as a collective farm chairman, was twice a deputy in Moscow, and now I'm finished, I'm 62. Is it my job to carry logs on me? Some of my children are dead, still another child is sick, and I am like an enemy, this is end in any case (AP RK: 186).

In the words of Magomedov Akhmad:

We were specially sent by the Soviet government to Kazakhstan to die of hunger, because we are now very few, many Chechens died of starvation, thousands of innocent languish in prisons (AIAD EKR: 3527). 
Repression against special settlers did not stop even after the end of military actions. Out of the total number of special settlers during 1949, 75$85 \%$ were repressed again and sent to camps, 5 $15 \%$ were hiding from authorities, $7-10 \%$ were arrested for violations of the regime and political crimes(AIAD EKR: 3534$){ }^{4}$

Rumours about return were considered as crimes, such as:

... the deported Chechens will be sent back to the North Caucasus, it is not necessary to work, but sell things; it will not be allowed to carry more than 2 poods (about $32 \mathrm{~kg}$ ) (SAEKR: 3997).

... it is impossible to live in the Soviet country, the collective farm is the prison for people, and we, Chechens, work in this prison ... (SAEKR: 80).

For the first time in documents, we found a hymn of special settlers from the Caucasus. The archival text was typed in Russian translated from Chechen. Deported to the east of Kazakhstan, the Chechen people sang a song about how they were moved from the Caucasus. The song called for not forgetting the day of resettlement. The NKVD organs recognised the song as anti-Soviet, hostile. Shalman Suleimanov was accused of singing the song of religious antiSoviet content at Chechen gatherings with slander against the Soviets since 1948.

Do you remember, Sharpudin, how we were driven out in the marketplace?

That evening they announced to us,

That all Chechens must part with their homeland.

What a sad evening it was for us.

They separated old men from the young just as the farm's cattle,

And made two groups.

After separating us, our wives and children returned home, shedding tears.
We must not forget that evening and that morning.

In the collective farm yard, we were placed into vehicles under escort, just as cattle.

Do you remember, Sharpudin! The trains were at the stations.

To take us to Far Siberia.

Do you remember, friends, that we addressed the Great Allah (Mubarik Khodzha)?

We asked Him for help.

We also must not forget how we were separated from our relatives,

And scattered throughout Siberia (Kazakhstan).

We must remember forever how we were forced to move.

We ask You, Mubarik Khodzha (Allah) to help us in Black Siberia.

We live deprived.

How happy you are, the Sun.

You shine and see the North Caucasus!

We did not recognise our God,

But He still proved.

We should not forget God (AIAD EKR: 3523).

The song has no author. Shalman Suleimanov first heard it in Semipalatinsk in 1947 in the performance of Khasan, special settler from the Charsky region. He memorised it and added to its content, calling Kazakhstan as Siberia and later sang it at Chechen meetings.

There are no words in the translation of the song that were mentioned by the singers, such as:

What a morning it was, with the golden sun. Do you remember how they drove us under arms to the mosques; put into echelons, arrested honourary people?

\footnotetext{
${ }^{4}$ Note: The calculation was made by the authors on the basis of the documents of the SAEKR. F.462. I.4. Sh. 80.
} 
How our wives, mothers and children cried? How the Soviet government mocked us, deprived us of human rights, of everything that Allah gave us? (AIAD EKR: 3523).

For this song Shalman Suleimanov and Minkail Visayev were sentenced to 20 years in 1951; in 1954 their sentences were reduced to 8 years.

The arrests of citizens from the deported population in East Kazakhstan, their secondary exile to other regions, make it possible to declare the secondary nature of reprisals or the second wave of punitive actions directed against individual subjects who protested, defied the regime (Lackwood, 2017).

\section{Discussion}

The proposed topic of the article is not limited to the deportation of the Chechen people. Koreans, Germans, Poles and other ethnic groups, including Chechens, were deported to the territory of Kazakhstan (Polyan, 2001; Repina, 2011). The problematic field of the forcible relocation of the Chechen people to Kazakhstan is actively explored and discussed in the historical, scientific space in the focus of analysis of archival materials, oral history - memories of both eyewitnesses and their descendants. Most authors consider this topic in the prism of tragic events, crimes against the Chechen people, integration of deported Chechens in the places of settlement, etc.

The format and structure of the contents of oral history, in particular the fact of unexpectedness of deportation, the violence used by the security forces, the conditions for the transportation of deportees, which resulted in the tragic death of people who could not stand the stage of resettlement, are common to authors based on oral memoirs of deported Chechens. Analysing the memories of settling in new places, employment and relations with the local population of deported Chechens, the authors focus on the help of the local population.

At the same time, the content of the proposed research, based on materials first introduced into scientific circulation, demonstrates the hidden opposition of deported Chechens, the strategy and tactics of survival in the new conditions. In particular, attempts to change the social status of the special settler; reaching and exceeding target indicators on the one hand and attempts to preserve the historical memory of the tragic events, on the other hand.

\section{Conclusion}

Archival sources and field research materials of the regional component of the deportation of the Chechen people made it possible to disclose some dramatic pages in the genre of oral history, a micro-historical approach; to see an individual attitude to the past and to take into account documentary evidence of the past.

Special settlers from the Caucasus got into unusual climatic conditions, did heavy physical work, lived in unsuitable premises. Lack of food rations, warm clothing, and high mortality contributed to the appearance of embitterment, hostility (Burds, 2007). There were cases of open speeches. The everyday space of the special settlement and its infrastructure represented a minimal set of life-support for special settlers, which was absolutely inadequate for survival. It should be noted that the local population, along with the authorities, provided all possible assistance to special settlers.

In the conditions of deportation, the settlers experienced a whole range of unfavourable influences, from natural climatic features of the region to artificially created problems, for example, denial of medical care for a special contingent, shortage of food and clothing. The problems are understandable from wartime, the socio-economic situation, the bureaucratic approach of the regional authorities, the undeveloped infrastructure, etc.

We cannot talk about the complete disregard of the regional authorities towards special settlers. The facts testify to the attempts of the party bodies in the localities to resolve issues with the resettlement and employment of Chechens.

The strategy of behaviour and adaptation of the Chechens differed in their internal relation to the status of the deported, expelled people. The dispersed state of the Chechen special settlers and their frontier conditioned the strategy and 
tactics of survival. Those who could not adapt entered the path of conflict, violation of legal norms. It was made in order to save their families (the theft for the rescue of the hungry was perceived as heroism). Those who gave up understood the senselessness of the confrontation and the need for survival in the new conditions, went on a dialogue with local authorities, which can be designated as a frontier interaction.

\section{References}

Archive of Internal Affairs Department of the East-Kazakhstan region, 19(2): 3526- 128.

Archive of Internal Affairs Department of the East-Kazakhstan region, 19(2): 3521-30.

Archive of Internal Affairs Department of the East-Kazakhstan region, 19(2): 3527-100.

Archive of Internal Affairs Department of the East-Kazakhstan region, 19(2): 3534-58.

Archive of Internal Affairs Department of the East-Kazakhstan region, 19(2): 3523-51.

Archive of the President of the Republic of Kazakhsta, 708(8): 113-211.

Archive of the President of the Republic of Kazakhstan, 708(8): 186-113.

Assman, Ya. (2004). Cultural Memory: Letter, Memory of the Past and Political Identity in the High Cultures of Antiquity. M.: Languages of Slavic Culture.

Braber, B. (2013). This Cannot Happen Here: Integration and Jewish Resistance in the Netherlands, 1940-1945. Amsterdam: Amsterdam University Press. Retrieved from http://www.jstor.org/stable/j.ctt6wp7hh

Bugay, N.F. (2003). According to the decision of the government of the Union of Soviet Socialist Republics (pp. 928). Nalchik: El-fa.

Bugay, N.F. (2011). L. Beria to I. Stalin: "After your instructions, the following is done ..." (pp. 510). M.: "Grif and K".

Bugay, N.F. (2012). Problems of repression and rehabilitation of citizens: history and historiography (XX century - the beginning of the XXI century) (pp. 480). Moscow: Grif and K.
Burds, J. (2007). "The Soviet war against 'fifth columnists': The case of Chechnya 1942-1944." Journal of Contemporary History, 42(2): 267-314.

Cameron, M. (2017). "Strangers in a Cruel Land: The wretched state of immigration enforcement." The Baffler, 34: 118-124.

Gelb, M. (2000). "Ethnic cleansing in the USSR, 1937-1949." Russian Review, 59(3): 472-474.

Halbwachs, M. (2005). "Collective and historical memory." Inviolable stock 2/3(40/41).

Hasselberg, I. (2016). Enduring Uncertainty: Deportation, Punishment and Everyday Life. NEW YORK; OXFORD: Berghahn Books.

Lackwood, M. (2017). "Fatima Gabitova: repression, subjectivity and historical memory in Soviet Kazakhstan." Central Asian Survey, 36(1): 113-130.

Lupu, N., L. Peisakhin. (2017). "The Legacy of Political Violence across Generations." American Journal of Political Science, 61(4): 836-851.

Mannheim, K. (1998). "The problem of generations." New literary review 2(30): 7-47.

Martin, T. (1999). "Borders and ethnic conflict: The Soviet experiment in ethno-territorial proliferation." Jahrbucher fur geschichte Osteuropas, 47(4): 538-555.

Middlemiss, L. (2017). Writing history in the Soviet Union: making the past work. Routledge.

Musial, B. (2013). "The 'Polish Operation' of the NKVD: The Climax of the Terror Against the Polish Minority in the Soviet Union." Journal of Contemporary History, 48(1): 98-124.

Pedersen, M. B. (2015). "MYANMAR IN 2014:'Tacking Against the Wind'." Southeast Asian Affairs, 1: 221-245.

Pohl, J. (2015). "The Persecution of Ethnic Germans in the USSR during World War II." The Russian Review, 75: 284-303.

Polyan, P.M. (2001). Not on their own will: History and geography of forced migrations in the USSR (pp. 328). Moscow: OGI-Memorial. 
Polyan, P.M. (1999). "Geography of forced migrations in the USSR." Izvestiya RAN. Geographic series, 6: 55-62.

Repina, L.P. (2011). "Historical science at the turn of XX - XXI centuries." Social theories and historiographical practice (pp. 560). Moscow: Krug.

Roginskij, A. (2017). "Fragmented Memory Stalin and Stalinism in Today's Russia." Osteuropa, 1112: 81-88.

Saveleva, I., A. Poletaev. (2003). "Knowledge of the past: theory and history: in 2 t." Designing of the past.

Scarborough, I. (2017). "An unwanted dependence: Chechen and Ingush deportees and the development of state-citizen relations in late-Stalinist Kazakhstan (1944-1953)." Central Asian Survey, 36(1): 93-112.

The State Archives of the East Kazakhstan Region 1(1): 2739-158.

The State Archives of the East Kazakhstan Region 1(1): 2741-53.

The State Archives of the East Kazakhstan Region 1(1): 2750-140.

The State Archives of the East Kazakhstan Region 1(1): 3420-40.

The State Archives of the East Kazakhstan Region 1(1): 3997-34.

The State Archives of the East Kazakhstan Region 130(22): 7-149.

The State Archives of the East Kazakhstan Region 462(4): 39-296.
The State Archives of the East Kazakhstan Region 462(4): 80-248.

Walters, W. (2002). "Deportation, Expulsion, and the International Police of Aliens." Citizenship Studies, 6: 265-292.

Williams, B. (2002). "The Hidden Ethnic Cleansing of Muslims in the Soviet Union: The Exile and Repatriation of the Crimean Tatars". Journal of Contemporary History, 37(3): 323-347. Zhanbossinova, A.S., Kazbekova A.T. (2014). Informant Kairat Kairatov. Ridder, Field expedition diary in Ridder.

Zhanbossinova, A.S., Kazbekova A.T. (2014). Informant Aisa Aisagova, born in 1945. Ridder, East-Kazakhstan region, Field expedition diary in Ridder.

Zhanbossinova, A.S., Kazbekova A.T. (2016). Informant Bertan Bertanov, born in 1939, UstKamenogorsk. East-Kazakhstan region, Field expedition diary in Ust-Kamenogorsk.

Zhanbossinova, A.S., Kazbekova A.T. (2016). Informant Musa Musaeva, born in 1918, NovoAzovoye village. Field expedition diary in NovoAzovoye village, East-Kazakhstan region.

\section{Acknowledgements}

The article is written in the framework of the project of the Control Committee of the Ministry of Education and Science of the Republic of Kazakhstan, IRN: AP05130870 "Memory of the victims of political repression (1920-1950s) and its fixation in the sacral landscape of Kazakhstan" (on the example of East Kazakhstan). 